\section{Case Reports in Dermatology}

\title{
Efficacy and Tolerability of Polyphenon E in "Difficult-to-Treat" Multiple Genital Warts in an HIV-Positive Male Subject
}

\author{
Mauro Grandolfo ${ }^{a} \quad$ Massimo Milani $^{b}$ \\ aSexual Transmitted Disease Clinic Policlinico "G. Cesare," University of Bari, Bari, Italy; \\ ${ }^{\mathrm{b}}$ Medical Department, Difa Cooper, Caronno, Italy
}

\section{Keywords}

AIDS - Condylomata acuminata · Polyphenon E

\begin{abstract}
A 55-year-old man, nonsmoker, with a HIV-positive history came to our attention in February 2017. He was on treatment with Stribild ${ }^{\top M}, 1$ capsule daily $(150 \mathrm{mg}$ elvitegravir, $150 \mathrm{mg}$ cobicistat, $200 \mathrm{mg}$ emtricitabine, and $245 \mathrm{mg}$ tenofovir disoproxil). The CD4+/CD8+ cellular count was 326/ $\mu \mathrm{L}$ (normal values: $404-1,612$ ); the CD3+/CD8+ cellular count was $819 / \mu \mathrm{L}$ (normal values: $220-1,219$ ). The CD4/CD8 ratio was 0.40 (normal value: $>1$ ). Several typical genital wart lesions were present at the penis shaft and at the level of the neck and the corona of glans. These lesions were present for 2 years. Several cryotherapy sessions (a total of 10 procedures) had been performed with partial success. At the initial visit a total of 5 lesions were present. Treatment with topical Polyphenon E 10\% 3 times a day was prescribed and started. After 1 month of treatment the lesions were reduced to 2 . Treatment was very well tolerated. After 8 weeks of treatment no more lesions were observed and therefore a complete clearance was obtained. Local tolerability was evaluated to be very good by the patient.




\section{Introduction}

Genital warts (GW; condylomata acuminata) are a very common and contagious sexually transmitted disease caused by skin infection with human papillomavirus (HPV) [1]. HPV has a specific tropism for squamous stratified epithelium [2]. This infection is in general acquired through direct genital contact. Minor trauma facilitates the penetration of the virus. Penile shaft, glans, vulvar and perianal regions are commonly affected [3]. HPV infection is characterized by a relevant immune evasion mechanism that inhibits and delays the host immune response to the virus [4]. Genotypes 6 and 11 are the most common HPV involved in GW formation [5]. GW lesions manifest as variable in size and shape. Lesions could be soft papules or plaques on anogenital skin. Cryotherapy, podophyllotoxin, imiquimod, and laser therapy are commonly used in GW [6]. However, available treatments are in general still unsatisfactory due to low efficacy and clearance rate, low local tolerability, and high recurrence rate [7]. Topical Polyphenon E 10\% has been recently evaluated in immunocompetent subjects with multiple GW [8]. Polyphenon E, applied 3 times a day for up to 16 weeks, induced a complete clearance rate in more than $50 \%$ of patients [9]. In addition, the recurrence rate at 3 months after the conclusion of the therapy was particularly low $(<6 \%)$ [9]. Polyphenon E is a quantified extract of green tea leaves (Camellia sinensis) where the main active substance is epigallocatechin gallate (EGCG), a polyphenol substance which represents the major component of the catechin fraction [10]. EGCG has potent antioxidant, antiinflammatory and proapoptotic actions, which could explain its antiviral properties [11]. Recent data have shown that EGCG is able to modulate the cellular genes involved in Tolllike receptor production and in the mechanisms of apoptosis [12]. The product has shown a general good safety profile. Local skin reactions like erythema and edema, in general mild to moderate, were reported in most treated subjects [13]. No data are available regarding the efficacy and the tolerability of Polyphenon E in immunocompromised subjects. We report the clinical efficacy and the tolerability of Polyphenon E 10\% ointment (Veregen ${ }^{\mathrm{TM}}$; Medigene, Germany) in an HIV-positive subject with multiple "difficult-to-treat" GW.

\section{Case Description}

A 55-year-old man, nonsmoker, with a HIV-positive history came to our attention in February 2017. He was on treatment with Stribild ${ }^{\mathrm{TM}}, 1$ capsule daily (150 mg elvitegravir, $150 \mathrm{mg}$ cobicistat, $200 \mathrm{mg}$ emtricitabine, and $245 \mathrm{mg}$ tenofovir disoproxil). The CD4+/CD8+ cellular count was 326/ $\mu \mathrm{L}$ (normal values: 404-1,612); the CD3+/CD8+ cellular count was 819/ $\mu \mathrm{L}$ (normal values: $220-1,219$ ). The CD4/CD8 ratio was 0.40 (normal value: $>1$ ). Several typical GW lesions were present at the penis shaft and at the level of the neck and the corona of glans (Fig. 1). These lesions were present for 2 years. Several cryotherapy sessions (a total of 10 procedures) had been performed with partial success. At the initial visit a total number of 5 lesions were present (Fig. 1). Treatment with topical Polyphenon E 10\% 3 times a day was prescribed and started. After 1 month of treatment the lesions were reduced to 2 . Treatment was very well tolerated. After 8 weeks of treatment no more lesions were observed and therefore a complete clearance was obtained (Fig. 2). Local tolerability was evaluated to be very good by the patient. 


\section{Discussion}

Polyphenon E ointment is considered an effective, well-tolerated, self-applicable topical treatment of GW in immunocompetent subjects [14]. Clinical efficacy and tolerability was evaluated in randomized vehicle-controlled phase III trials in more than 1,000 patients [15]. A complete clearance rate was observed in $51 \%$ of the treated subjects. The mean treatment duration for complete clearance was between 14 and 16 weeks [16]. GW are very common in immunocompromised subjects [17]. HIV infection appears to alter the natural history of HPV-associated lesions and oncogenesis [18], and HIV-positive patients have a substantial high risk of suffering from GW in comparison with HIV-negative immunocompetent subjects. HIV-positive patients often develop multiple papillomatous lesions in the genital area and also in the extragenital area such as the oral cavity [19]. Goldstone et al. [20] have demonstrated that in HIV subjects the prevalence of any tested HPV type was 18.5\% in the penis, $17.1 \%$ in the scrotum, $33.0 \%$ in the perineal/perianal region, $42.4 \%$ in the anal canal, and $48.0 \%$ at any site. Antiretroviral therapy is not able to prevent the development of HPVassociated lesions and does not eliminate HPV infection [21]. The treatment of GW in immunocompromised subjects can be particularly disappointing. Data regarding the efficacy of Polyphenon E in immunocompromised subjects are so far lacking. EGCG has an antiviral action through pathways triggering cell growth arrest and increasing proapoptotic molecules like p53 and p16 [22]. EGCG is able to interfere with the cellular activity of E6 and E7, 2 HPV virus proteins [23]. E6 and E7 are involved in the process of apoptosis inhibition and in the mechanisms of immune evasion [24]. Therefore, Polyphenon E could express anti-HPV action through multiple mechanisms. The gene modulation expressed by EGCG could be of help in fighting HPV lesions in HIV patients. In this case report, we have shown a high clinical efficacy of Polyphenon E in the treatment of multiple "difficult-to-treat" GW in an HIVpositive subject. It is remarkably that complete clearance of GW lesions was achieved in only 8 weeks of treatment, which is a shorter treatment period in comparison with the mean duration of treatment for GW clearance in immunocompetent patients. This case report suggests that topical Polyphenon E 10\% could be an effective therapeutic strategy in subjects with GW and immunosuppression. Specific controlled trials in this specific population are warranted.

\section{Statement of Ethics}

The authors have no ethical conflicts to declare.

\section{Disclosure Statement}

M.M. is an employee of Difa Cooper Spa. 


\section{References}

1 Handsfield HH: Clinical presentation and natural course of anogenital warts. Am J Med 1997;102:1620.

2 Majewski S, Jablonska S: Human papillomavirus-associated tumors of the skin and mucosa. J Am Acad Dermatol 1997;36:659-685.

-3 Ferenczy A, Mitao M, Nagai N, Silverstein SJ, Crum CP: Latent papillomavirus and recurring genital warts. New Engl J Med 1985;313:784-788.

4 Tindle RW: Immune evasion in human papillomavirus-associated cervical cancer. Nat Rev Cancer 2002;2:59-64.

-5 Gissmann L, Wolnik L, Ikenberg H, Koldovsky U, Schnürch HG, Zur Hausen H: Human papillomavirus types 6 and 11 DNA sequences in genital and laryngeal papillomas and in some cervical cancers. Proc Natl Acad Sci USA 1983;80:560-563.

-6 Sterling JC, Handfield-Jones S, Hudson PM: Guidelines for the management of cutaneous warts. Br J Dermatol 2001;144:4-11.

7 Kodner CM, Nasraty S: Management of genital warts. Am Fam Physician 2004;70:2335-2342.

-8 Tatti S, Stockfleth E, Beutner KR, Tawfik H, Elsasser U, Weyrauch P, Mescheder A: Polyphenon E ${ }^{\circledR}$ : a new treatment for external anogenital warts. Br J Dermatol 2010;162:176-184.

-9 Stockfleth E, Beti H, Orasan R, Grigorian F, Mescheder A, Tawfik H, Thielert C: Topical Polyphenon® E in the treatment of external genital and perianal warts: a randomized controlled trial. $\mathrm{Br} J$ Dermatol 2008;158:1329-1338.

10 Waltner-Law ME, Wang XL, Law BK, Hall RK, Nawano M, Granner DK: Epigallocatechin gallate, a constituent of green tea, represses hepatic glucose production. J Biol Chem 2002;277:34933-34940. Valcic S, Muders A, Jacobsen NE, Liebler DC, Timmermann BN: Antioxidant chemistry of green tea catechins. Identification of products of the reaction of $(-)$-epigallocatechin gallate with peroxyl radicals. Chem Res Toxicol 1999;12:382-386.

12 Masuda M, Suzui M, Weinstein IB: Effects of epigallocatechin-3-gallate on growth, epidermal growth factor receptor signaling pathways, gene expression, and chemosensitivity in human head and neck squamous cell carcinoma cell lines. Clin Cancer Res 2001;7:4220-4229.

13 Tatti S, Swinehart JM, Thielert C, Tawfik H, Mescheder A, Beutner KR: Sinecatechins, a defined green tea extract, in the treatment of external anogenital warts: a randomized controlled trial. Obstet Gynecol 2008;111:1371-1379.

14 Tzellos TG, Sardeli C, Lallas A, Papazisis G, Chourdakis M, Kouvelas D: Efficacy, safety and tolerability of green tea catechins in the treatment of external anogenital warts: a systematic review and meta-analysis. J Eur Acad Dermatol Venereol 2011;25:345-353.

15 Gupta AK, Daigle D: Sinecatechins 10\% ointment: a green tea extract for the treatment of external genital warts. Pain 2015;46:14-15.

16 Stockfleth E, Meyer T: The use of sinecatechins (Polyphenon E) ointment for treatment of external genital warts. Expert Opin Biol Ther 2012;12:783-793.

17 Jin F, Prestage GP, Kippax SC, Pell CM, Donovan B, Templeton DJ, Grulich AE: Risk factors for genital and anal warts in a prospective cohort of HIV-negative homosexual men: the HIM study. Sex Transm Dis 2007;34:488-493.

18 Del Mistro A, Bianchi LC: HPV-related neoplasias in HIV-infected individuals. Eur J Cancer 2001;37:1227-1235.

19 Greenspan D, Viliers EM, Greenspan JS, Souza YG, Hausen H: Unusual HPV types in oral warts in association with HIV infection. J Oral Pathol Med 1988;17:482-487.

20 Goldstone S, Palefsky JM, Giuliano AR, Moreira ED, Aranda C, Jessen H, Marshall JB: Prevalence of and risk factors for human papillomavirus (HPV) infection among HIV-seronegative men who have sex with men. J Infect Dis 2011;203:66-74.

21 Del Mistro A, Bertorelle R, Franzetti M, Cattelan A, Torrisi A, Giordani MT, Minucci D: Antiretroviral therapy and the clinical evolution of human papillomavirus-associated genital lesions in HIV-positive women. Clin Infect Dis 2004;38:737-742.

-22 Thakur VS, Amin AR, Paul RK, Gupta K, Hastak K, Agarwal MK, Agarwal ML: p53-dependent p21mediated growth arrest pre-empts and protects HCT116 cells from PUMA-mediated apoptosis induced by EGCG. Cancer Lett 2010;296:225-232.

-23 Qiao Y, Cao J, Xie L, Shi X: Cell growth inhibition and gene expression regulation by (-)-epigallocatechin3-gallate in human cervical cancer cells. Arch Pharm Res 2009;32:1309-1315.

24 Park JS, Kim EJ, Kwon HJ, Hwang ES, Namkoong SE, Um SJ: Inactivation of interferon regulatory factor-1 tumor suppressor protein by HPV E7 oncoprotein. Implication for the E7-mediated immune evasion mechanism in cervical carcinogenesis. J Biol Chem 2000;275:6764-6769. 


\section{Case Reports in Dermatology}

\begin{tabular}{l|l}
\hline Case Rep Dermatol 2017;9:55-59 \\
\hline DOI: 10.1159/000477839 & $\begin{array}{l}\text { @ 2017 The Author(s). Published by S. Karger AG, Basel } \\
\text { www.karger.com/cde }\end{array}$ \\
\hline
\end{tabular}

Grandolfo and Milani: Efficacy and Tolerability of Polyphenon E in "Difficult-to-Treat" Multiple Genital Warts in an HIV-Positive Male Subject

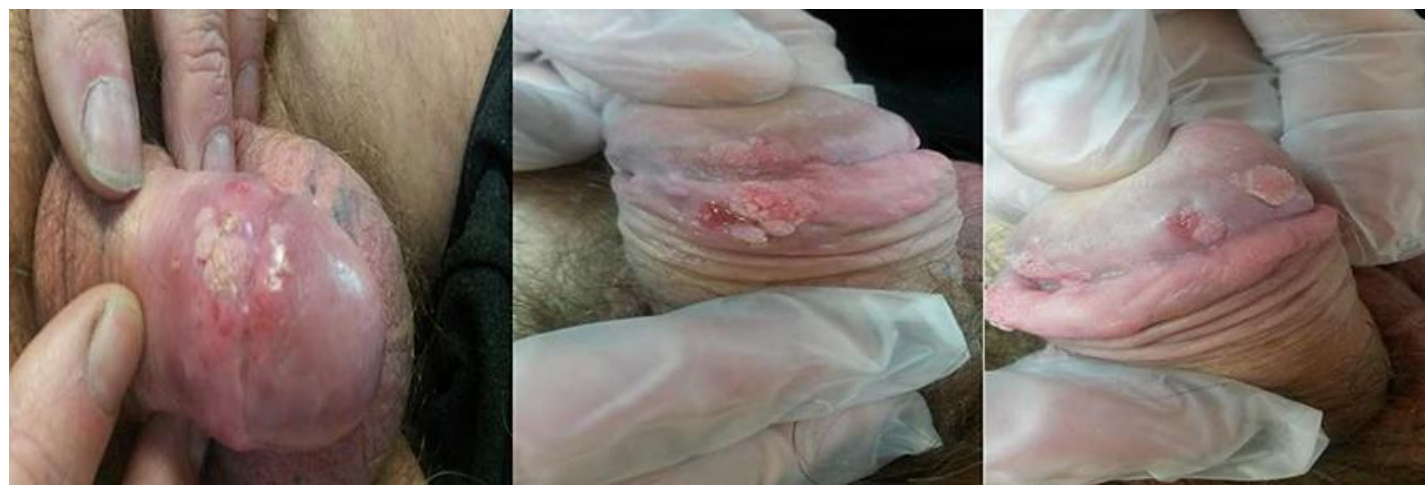

Fig. 1. Genital warts at baseline. Multiple lesions.

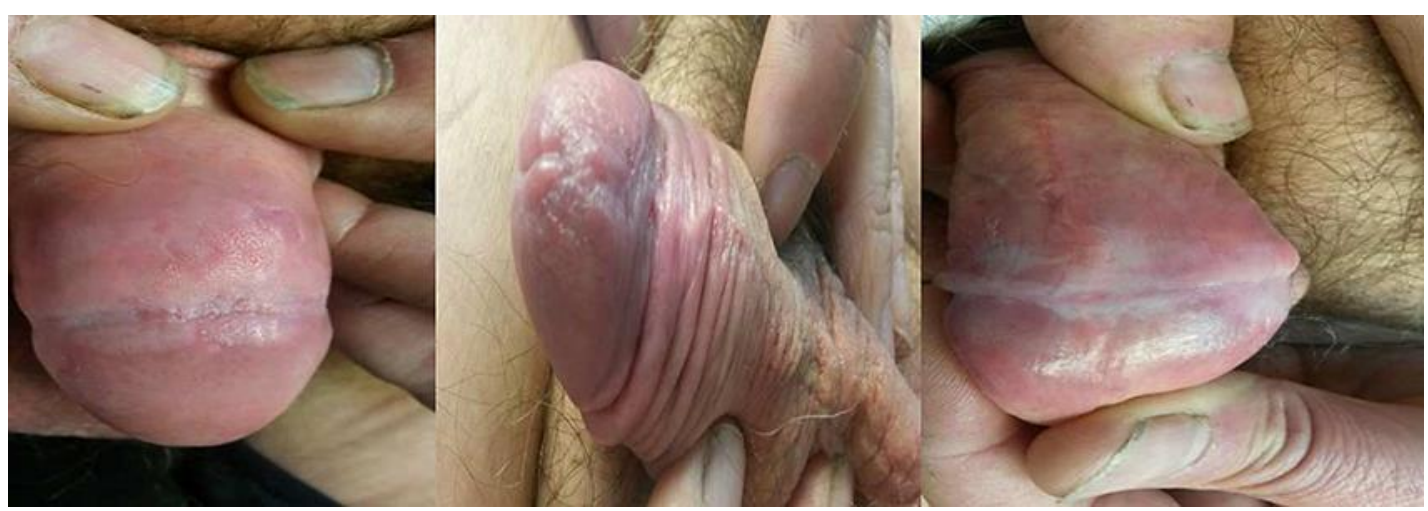

Fig. 2. Genital warts after 2 months of treatment with Polyphenon E. 